\title{
PERSONAL NEED FOR STRUCTURE, COUNTERFACTUAL THINKING AND DECISION MAKING IN WOMEN
}

\author{
Alexandra PROKOPČÁKOVÁ \\ Institute of Experimental Psychology, Slovak Academy of Sciences \\ Dúbravská cesta 9, 84104 Bratislava, Slovak Republic \\ E-mail: expspro@savba.sk
}

\begin{abstract}
The aim of the study is to clarify the mutual relationships between personal need for structure, counterfactual thinking and decision making styles. The research sample comprised 76 university students. The following scales were administered: Personal Need for Structure (PNS), Melbourne Decision Making Questionnaire (MDMQ), Decision Making Style Questionnaire (DMSQ) and Counterfactual Thinking Questionnaire (CT). Results revealed that personal need for structure and its subfactors do not affect an individual's behavior in the decision making process, but they do affect the decision making style when it comes to the desire for structure or the response to the lack thereof. A strong desire for structure is more related to a more frequent use of rational and dependent decision making style, while a weak response to the lack of structure is related to a more frequent use of the intuitive decision making style and less frequent avoidance decision making style. Additionally, the results show that counterfactual thinking characteristics are related mainly to maladaptive styles of decision making behavior.

Key words: personal need for structure, decision making style, decision making behavior, counterfactual thinking
\end{abstract}

People live in a complicated world of information. Large amounts of information that flood human senses and a limited capacity of one's concentration raise the important question of information processing. Without processing the stimuli affecting a person's senses, the world would be an unimaginable chaos for him/her.

In the process of mutual interaction with the environment, a person forms structural representations of the inner and outer worlds and categorizes events into meaningful units that can be helpful in adapting to new situations and understanding individual events without extreme cognitive strain.

This study was partially supported by the grant agency VEGA no. 2/0126/12.
The subject matter of cognitive structuring relates, to a considerable degree, to personal need for structure, cognitive decision making, choice of alternatives (even past or future ones), categorization, etc., and researchers look for determinants (e.g., personality characteristics) which are concerned with the preferred way of information processing, decision making and coping strategies.

\section{PERSONAL NEEDFOR STRUCTURE}

If the primary motive for categorization is to provide structure, and if there are individual differences in the manner and extent how people categorize their social world, then one of the variables differentiating individuals is personal need for structure. In reality,

DOI: $10.21909 /$ sp.2014.03.659 
personal need for structure is one of the motives that can automatically influence perception and behavior due to its ability to direct cognition and behavior in various situations.

Blais, Thompson and Baranski (2003) say that, in general, personal need for structure appears when a person desires structure, order and consistency. Personal need for structure is considered adaptive, making it easier for an individual to control and predict events in the complicated word (Cohen, Stotland, Wolfe, 1955; Neuberg, Newsom, 1993).

According to Sollár (2005), cognitive structuring helps to achieve certainty by filtering inconsistent or irrelevant information. Such structures can reduce an individual's cognitive strain because they are "simple" - relatively homogenous, well defined and distinguishable from other structures - thus, helping to clearly interpret new events. The more heterogeneous the structures and more vague the boundaries, the less useful they are for an effective characterization of new events and situations.

Kruglanski and his team (Kruglanski, Freund, 1983; Kruglanski, 1989) conceptualized the need for cognitive structure as a situational motive, activated in situations of distress (e.g., time pressure in decision making), as a desire for clear and permanent knowledge on a certain topic, as an opposite to ambiguity, doubt and chaos.

Sarmány-Schuller (2001) says that this personality construct is related to the more basic process of categorization, which helps one to understand and differentiate the vast amount of information flooding an individual every day. Categorization based on comparison of individual stimuli (situations) makes it possible to explore things under their sur- face and to understand the concealed rules based on the work with category's elements.

Wolfradt and Engelmann (1999) define personal need for structure as a personality tendency to "structure the world into an unambiguous, manageable form", with the aim to reduce personal vagueness, resulting from new events and situations.

Stranovská et al. (2011) describe the ability to form cognitive structure as the ability to reduce the vagueness of a situation. It is a way how an individual perceives and processes information on uncertain and unexpected stimuli and situations.

According to Bar-Tal et al. (1999), personal need for structure is often defined as a dimension oscillating between two extremes the first one, an individual's predisposition for using cognitive structuring to achieve security and the second one, related to the strong tendency for continuous, systematic processes of information processing.

Thompson et al. (2011) defined personal need for structure as a desire for clarity, definiteness and aversion to indefiniteness. Tolerance to indefiniteness is a way of perceiving and processing information on indefinite stimuli and situations, or situations perceived as indefinite.

Neuberg and Newsom (1993) say that personal need for structure describes individual differences to the extent in which individuals actively seek and prefer structure. Personal need for structure is defined as the preference to use cognitive structuring to achieve definiteness; it is in particular the creation and use of abstract mental representations (schemas, patterns, scenarios, and stereotypes) that are simplified generalizations of individual's previous experience.

Very common argument found in literature concerns the factor structure of the personal 
need for structure construct, based on two prevalent opinions. One is based on the statement that personal need for structure construct is unidimensional, comprising only one dimension. Supporters of this statement are Thompson, Naccarato and Parker (Thomson et al., 2001). The second opinion - that this construct comprises two factors - is supported by Neuberg and Newsom (1993), who identified two independent factors by means of factor analysis.

One factor concerns the extent to which people wish to establish cognitive structure in everyday life, i.e., the desire for (simple cognitive) structure (related to positive affect as a response to a predictable person and well-organized events). People with high scores in this item prefer a clear and structured life and a set place for everything.

The other factor of PNS, response to the lack of (simple cognitive) structure (related to negative affect as a response to a chaotic, unorganized event and unpredictable persons) concerns how people respond to unstructured and unpredictable situations. People who dislike uncertain situations or sudden, last moment changes in their plans are considered high scoring in this item.

These two factors have different relationships with different personality constructs (Neuberg, Newsom, 1993), thus, in general, they possess different implications for how people understand, experience and interact with their environment.

Authors of the personal need for structure construct designed the "Personal Need for Structure Scale (PNS)" for its assessment. The scale was originally based on a one-factor model, but was later modified to a twofactor model of personal need for structure, where one subfactor is related to the desire for structure (DFS) and the other factor is related to the response to the lack of structure (RLS) (Neuberg, Newsom, 1993). The Slovak version of this scale was prepared by Sarmány-Schuller and its two-factor structure was verified by Sarmány-Schuller (1997) and Sollár (2005).

Based on his research, Sarmány-Schuller (2009) says that individuals with high personal need for structure prefer simple organization of information, less complex memory structures and relatively simple reasoning, thinking, and decision making.

According to Blaise, Thompson and Baransky (2003), individuals with high personal need for structure are characterized by decisiveness based on high self-esteem and quick reaction time. These people base their judgments to a large extent on initial information and they are more resistant to associated contradictory evidence (Kaplan, Wanshula, Zanna, 1991). Also according to Neuberg and Newsom (1993), these individuals are, in comparison to people with low personal need for structure, more affected by initially created categories and stereotypes. People with high personal need for structure tend to sort information into a lower number of groups and cognitively less complex structures.

Thus, studies show that personal need for structure affects the complexity of deductive reasoning strategies and related decision making of individuals.

\section{DECISIONMAKING}

The problem of decision making concerns practically the whole human life. In the decision making process an individual chooses one alternative from several, i.e., as stated by Čerešník (2012), s/he seeks some dominant structure, whereas one of the alterna- 
tives is better than the other in at least one attribute.

History of decision making research has proceeded from classical normative theories (trying to explain how people should make decisions according to principles of logic, mathematics and statistics) to descriptive theories which attempted to study and explain common, everyday decision making (Konrádová, Mihálik, 2011).

The first model of human decision making was the classic theory of decision making, based on the advantages of economy, thus creating and applying mathematical models to human behavior. However, this model expects full awareness of alternatives and their consequences, sensitivity to small differences between alternatives and rationality in maximizing the benefit (Sternberg, 2002).

The theory of rational decision making is a normative theory that takes rationality into consideration. Čerešník (2012) says that according to this theory, the role of the decision maker is to choose methods maximizing the results, disregarding the consequences of these methods on others.

Maximizing the benefit is a universal explanation of human behavior within this theory; it is the very nature of man. Normative theory principles appear as indisputable, as they are related to the logic of the decision making process and to the preference of the most advantageous alternative (Bačová, 2011b).

The rational model of decision making soon became strongly criticized. The best known criticism is by Herbert Simon (in Bačová, 2011a) who argued that basic requirements of rational decision making models disregard the limited cognitive possibilities of humans. The classical rationality model expects and requests the knowledge of all relevant alternatives of choice, the knowledge of all consequences and probabilities. It is based on the assumption of unlimited abilities of man as an absolutely rational decision maker, who avoids logical mistakes, can solve mathematical problems, processes all available information in the required time, fully comprehends problems and consequences of his/ her own decisions, knows well all the alternatives and knows exactly which alternatives $\mathrm{s} /$ he prefers and why $\mathrm{s} / \mathrm{he}$ is consistent in his/her preferences.

Kahneman and Tversky studied how real people make decisions when faced with several alternatives. They found many discrepancies in the principles of rational thinking, thus arriving at the so-called descriptive theory of decision making, designating it the prospect theory (Kahneman, Tversky, 1979). Their prospect theory replaced rational and logical rules of decision making with psychological principles, at the same time maintaining mathematical precision and calculations of classical normative models (Bačová, 2011b).

In relation to the classical research of Simon, and Kahneman and Tversky, the study of decision making moved to the "ecological” context (Konrádová, Mihálik, 2011) by the end of the last century. According to some researchers, the study of cognitive processes detached from the environment can result in misleading findings (McKenzie, 2005). In regard to the environment affecting human decision making, Todd and Gigerenzer (2003) speak about ecological rationality. Gerd Gigerenzer confronts his approach with the approach of Kahnemen and Tversky (Bačová, 2011b).

Decision making theories, based on the criticism of classical normative models, fo- 
cused on people making decisions in their natural environment, characterized by chaos, indefiniteness, complicated nature, and complexness. While, according to normative theories, decision making is rational when it follows the norms of logic, statistics, and the theory of probability, according to the theories of ecological rationality, decision making is rational when it is adapted to the environment where a person acts and effectively achieves his/her goals. Bačová (2011a) emphasizes that the ecological rationality approach introduces the decision making context into the study of decision making: structure of tasks and environment. This is based on the idea that decision making that follows rational normative rules and correct decision making in real life situations are two different things. This approach separates rationality and correctness as two different standards of decision making and presents the image of man as an adaptive and adaptable decision maker (Bačová, 2011a).

According to the increasing consensus in cognitive psychology, individual differences can critically affect the decision making process. The way people think, the precision of their perception, how they process and remember information or how they use the information in problem solving falls under the term cognitive style (Sarmány-Schuller, 1987). Simuth and Sarmány-Schuller (2010) state that the way people think, gather information, and process this information influences the choices they make. Their research results (Šimúth, Sarmány-Schuller, 2011) confirm that cognitive style, which according to Ruisel (2004) is a relatively stable characteristic of an individual, can, to some extent, influence the way an individual makes decisions. Šimúth and Sarmány-Schuller (2013) also found significant relationships between ra- tional decision making style and the knowing dimension of cognitive style as well as planning style and a significant correlation between the avoidant decision making style and planning dimension of cognitive style.

As was said by Čerešník (2010), decision making is a multidimensional process affected by the decision maker's actions, task structure, personality characteristics and environment variables, but also by, e.g., counterfactual thinking, etc.

\section{COUNTERFACTUAL THINKING}

A part of almost all decision making of man, which is understood as a dynamic process of choosing between several alternatives, is counterfactual thinking defined as thinking about unrealized or possible alternatives. Counterfactual thinking is thinking about the 'what ifs', what would have happened if a different antecedent alternative occurred (as opposed to the real one) and about the result of the situation, if it would have been different or the same (different or the same consequences) (Ruiselová, 2009). It is usually triggered by failure in problem solving and it is a mental simulation of possible alternatives of solutions. It usually focuses on the past but there is a long discussion about its usefulness from the viewpoint of future problem solutions.

Similarly to the general topic of decision making, counterfactual thinking is also about considering several (in this case hypothetical) alternatives and comprises cognitive, evaluation and emotional processes.

Counterfactual thinking results from the fact that people are aware of alternatives which did not take place, nevertheless, these alternatives take effect henceforth (Bačová, 2009). In decision making, counterfactual 
thinking represents comparing of possible alternatives.

Counterfactual thinking plays a crucial part in Svenson's Differentiation and Consolidation Theory (Svenson, 2003). In this theory any individual who makes decisions has to find an alternative that surpasses all others. This can be achieved by differentiation, i.e., change in problem representation with the aim to emphasize the differences between alternatives (counterfactual comparison). If differentiation is achieved (decision is made), one of the alternatives is selected and the process of consolidation commences. This is to ensure that the individual continues to perceive the chosen alternative as the correct one, and protects him from negative emotions (counterfactual emotions).

According to Svenson's theory counterfactual thinking/comparing takes place before as well as after the decision was made. Prior to the decision, such a comparing enables a decision maker to evaluate alternatives of situations and choices. In this process, the individual anticipates consequences of counterfactuals, anticipates one's own future emotions, which will result from the decision.

Counterfactuals are dealt with in the Decision Affect Theory by Mellers et al. (1999) as well. This theory incorporates emotions into decision making using counterfactual comparisons. Counterfactual thinking - comparing counterfactuals (i.e., events which did not happen although they could happen)need not proceed only after the decision, but already before the decision, when an individual chooses one of several alternatives and compares possible future outcomes of these alternatives (i.e., events which did not take place). Counterfactual thinking full of emotions not only affects the decision mak- ing process, but it could be considered an inseparable component of decision making (Bačová, 2009).

\section{PROBLEM}

Problem solving, thinking and decision making is a highly complex process. Interindividual differences in this process, related to certain personality characteristics focusing on cognitive information processing, can be approached within the combination of cognitions and personality. "Good" decisions are possible only when complexity of psychological processes in decision making will be taken into account.

As the results of various studies (e.g., Sollár, 2005; Ruiselová, Prokopčáková, Kresánek, 2012) indicate that components of the Personal Need for Structure Scale as well as the characteristics of counterfactual thinking differ in their relationship to different personality characteristics, the presented research looks into the question whether the differences in personal need for structure and its components (desire for structure and response to lack of structure) are manifested in the preference of decision making styles and decision making behavior as well.

Based on the difference between desire for structure and response to lack of structure, the hypothesis to be verified by the research is that these two components of need for structure would relate to decision making styles as well as decision making behavior differently.

Moreover, it alsois presumed that individual characteristics of counterfactual thinking would be linked differently to decision making styles and decision making behavior.

The aim is to contribute to the explanation of the mutual relationship between personal 
need for structure, counterfactual thinking and decision making styles.

\section{METHOD}

Personal Need for Structure (PNS - Thompson, Naccarato, Parker, 1989, In: Neuberg, Newsom, 1993) is a self-report scale, where participants express their degree of agreement or disagreement (on a six point scale, 1 - completely disagree to 6 completely agree) with statements focusing on the structure of the environment. The scale measures two factors related to cognitive assessment:

- Desire for Structure (DFS)

- Response to Lack of Structure (RLS).

The scale comprises 12 items, of which 5 items form the subfactor "Desire for Structure" and 7 items form the subfactor "Response to Lack of Structure". The PNS factor is the sum of scores of both subfactors. Higher score indicates higher personal need for structure, similarly higher DFS score means higher preferences of simple structure in life and higher RLS score means stronger negative feelings in situations perceived by the individual as unsatisfyingly structured.

Melbourne Decision Making Questionnaire (MDMQ - Mann et al., 1997) - is a 22 item questionnaire for assessing decision making styles. It identifies 4 styles of decision making behavior (factors): vigilance (VIG) considered as adaptive style of behavior in decision making situations, and maladaptive styles of decision making are buck passing (BP), procrastination in the decision making process (PRO) and hypervigilance in decision making (HYP). These decision making styles are the most common approaches to decision making.
Responses are given on a 3 point scale ( 1 - applies to me to 3 - does not apply to me), i.e., the lower the score, the more preferred the given style in the decision making process.

Decision Making Style Questionnaire (DMSQ - Scott, Bruce, 1995) - comprises 4 subscales that follow 4 decision making styles:

RATDM subscale - Rational decision making style, characterized by decisions logically linked to the goal. Frequent is a conscious assessment of alternatives with the aim to choose the one seemingly most effective for achieving the goal.

INTDM subscale - Intuitive decision making style, characterized by decision making based on experience. An intuitive person focuses on the general concept of risk taking and does not consider the individual parts of the decision making process. The scale also includes emotional self-awareness as basis for decisions, low expectation for the future and low activity in collecting and assessing information on alternatives.

DEPDM subscale - Dependent decision making style, characterized by the need to support others in their decision making. Choice of an alternative depends on expectations and advice of others.

AVODM-Avoidant decision making style, characterized by avoidance of making a decision.

Responses are given on a scale from 1 fully agree to 5 - fully disagree, i.e., the lower the score, the more preferred the given decision making style.

Counterfactual Thinking Questionnaire (CT - Ruiselová, Prokopčáková, Kresánek, 2007) - 10 questions on quantitative and qualitative aspects of counterfactual thinking $(\mathrm{CT})$. 


\section{Sample}

The sample consisted of 76 female university students of psychology in Nitra (women: $\mathrm{n}=76$, mean age $=20.37, \mathrm{SD}=0.780)$. For research purposes, extreme groups were designed based on the \pm 1 SD criterion, individually by the score in DFS (desire for structure, low score $\mathrm{n}_{1}=13$ and high score $\mathrm{n}_{2}=$ 14), then by the score in RLS (response to lack of structure, low score $\mathrm{n}_{1}=16$ and high score $\mathrm{n}_{2}=11$ ) and by the overall score in PNS on the Personal Need for Structure Scale (low score $\mathrm{n}_{1}=13$ and high score $\mathrm{n}_{2}=8$ ).

Moreover, extreme groups were also created according to the characteristics of counterfactual thinking: according to the frequency of counterfactual thinking (infrequent $-\mathrm{n}_{1}=28$, frequent $-\mathrm{n}_{2}=48$ ), the saddening effect of counterfactual thinking (rarely saddens $-\mathrm{n}_{1}=44$, often saddens $-\mathrm{n}_{2}$ $=32$ ), whether counterfactual thinking helps or does not help in solving future problems (does not help $-\mathrm{n}_{1}=25$, helps $-\mathrm{n}_{2}=51$ ) and whether counterfactual thinking inhibits or does not inhibit solving of future problems (inhibits $-\mathrm{n}_{1}=52$, does not inhibit $-\mathrm{n}_{2}=24$ ).

\section{RESULTS}

Data was processed in the SPSS program, the extreme groups (groups designed based on the $\mathrm{AM} \pm 1 \mathrm{SD}$ criterion) were analyzed using Student's t-test.

\section{Personal Need for Structure and Decision Making}

The comparison of women with low and high desire for structure (DFS) (Table 1) showed that women with a low score in DFS used significantly less frequently rational, as well as dependent decision making style. Significant differences in intuitive, or avoidant decision making style between

Table 1. Comparison of women with low and high desire for structure in decision making styles, decision making behavior

\begin{tabular}{|c|c|c|c|c|c|c|c|c|c|}
\hline \multirow[t]{2}{*}{ Women } & \multicolumn{3}{|c|}{$\begin{array}{c}\text { Low desire for } \\
\text { structure }\end{array}$} & \multicolumn{3}{|c|}{$\begin{array}{l}\text { High desire for } \\
\text { structure }\end{array}$} & \multirow[t]{2}{*}{$\mathrm{t}$} & \multirow[t]{2}{*}{ sig } & \multirow[t]{2}{*}{$\mathrm{p}$} \\
\hline & N1 & AM1 & SD1 & $\mathrm{N} 2$ & AM2 & SD2 & & & \\
\hline $\begin{array}{l}\text { Decision Making Style Quest } \\
\text { DMSQ }\end{array}$ & & & & & & & & & \\
\hline Rational decision making & 12 & 21.00 & 4.492 & 13 & 14.85 & 3.671 & 3.732 & .001 & *** \\
\hline Intuitive decision making & 13 & 14.46 & 2.665 & 14 & 14.93 & 3.293 & .406 & .688 & \\
\hline Dependent decision making & 13 & 13.92 & 3.121 & 14 & 10.57 & 3.589 & 2.594 & .016 & $*$ \\
\hline Avoidant decision making & 13 & 17.54 & 2.696 & 14 & 14.93 & 3.852 & 2.051 & .052 & \\
\hline $\begin{array}{l}\text { Melbourne Decision Making } \\
\text { Questionnaire MDMQ }\end{array}$ & & & & & & & & & \\
\hline Vigilance & 13 & 11.92 & 1.498 & 14 & 11.57 & .646 & .782 & .446 & \\
\hline Buck-passing & 13 & 14.85 & 3.262 & 14 & 13.64 & 3.478 & .928 & .362 & \\
\hline Procrastination & 13 & 11.54 & 2.145 & 14 & 10.36 & 2.872 & 1.216 & .236 & \\
\hline Hypervigilance & 13 & 10.23 & 2.386 & 13 & 8.54 & 2.184 & 1.886 & .071 & \\
\hline
\end{tabular}


women with different degree of desire for structure were not found.

Similarly, no such differences were found in any of the studied decision making behavior styles.
A different situation occurred in the comparison of women with a different score in the response to lack of structure (RLS) (Table 2) and decision making styles studied by the Decision Making Style Questionnaire.

Table 2. Comparison of women with low and high response to lack of structure and decision making styles, decision making behavior

\begin{tabular}{|c|c|c|c|c|c|c|c|c|c|}
\hline \multirow[t]{2}{*}{ Women } & \multicolumn{3}{|c|}{$\begin{array}{c}\text { Low response to lack } \\
\text { of structure }\end{array}$} & \multicolumn{3}{|c|}{$\begin{array}{c}\text { High response to lack } \\
\text { of structure }\end{array}$} & \multirow[t]{2}{*}{$\mathrm{t}$} & \multirow[t]{2}{*}{ sig } & \multirow[t]{2}{*}{$\mathrm{p}$} \\
\hline & $\mathrm{N1}$ & AM1 & SD1 & N2 & AM2 & SD2 & & & \\
\hline \multicolumn{10}{|c|}{$\begin{array}{l}\text { Decision Making Style Questionnaire } \\
\text { DMSQ }\end{array}$} \\
\hline Rational decision making & 14 & 20.93 & 4.251 & 11 & 18.91 & 2.737 & 1.438 & .164 & \\
\hline Intuitive decision making & 15 & 13.33 & 2.895 & 11 & 15.45 & 1.968 & 2.223 & .036 & $*$ \\
\hline Dependent decision making & 16 & 14.75 & 2.082 & 11 & 12.09 & 3.833 & 2.098 & .054 & \\
\hline Avoidant decision making & 16 & 17.50 & 2.098 & 11 & 14.36 & 4.105 & 2.333 & .036 & $*$ \\
\hline \multicolumn{10}{|l|}{$\begin{array}{l}\text { Melbourne Decision Making } \\
\text { Questionnaire MDMQ }\end{array}$} \\
\hline Vigilance & 16 & 12.06 & 1.389 & 11 & 11.64 & 1.120 & .880 & .388 & \\
\hline Buck-passing & 16 & 14.88 & 3.757 & 11 & 13.55 & 4.204 & .843 & .409 & \\
\hline Procrastination & 16 & 11.50 & 2.530 & 10 & 12.00 & 1.563 & .623 & .539 & \\
\hline Hypervigilance & 16 & 10.50 & 2.503 & 11 & 9.55 & 1.508 & 1.234 & .229 & \\
\hline
\end{tabular}

Table 3. Comparison of women with low and high personal need for structure and decision making styles, decision making behavior

\begin{tabular}{|l|c|c|c|c|c|c|c|c|c|}
\hline \multirow{2}{*}{ Women } & \multicolumn{2}{|c|}{$\begin{array}{l}\text { Low personal need } \\
\text { for structure }\end{array}$} & \multicolumn{2}{c|}{$\begin{array}{c}\text { High personal need } \\
\text { for structure }\end{array}$} & \multirow{2}{*}{$\mathrm{t}$} & \multirow{2}{*}{ sig } & \multirow{2}{*}{$\mathrm{p}$} \\
\cline { 2 - 11 } & N1 & AM1 & SD1 & N2 & AM2 & SD2 & & & \\
\hline $\begin{array}{l}\text { Decision Making Style Questionnaire } \\
\text { DMSQ }\end{array}$ & & & & & & & & & \\
\hline Rational decision making & 11 & 21.36 & 4.523 & 8 & 17.38 & 1.408 & 2.748 & .017 & $*$ \\
\hline Intuitive decision making & 13 & 13.23 & 2.920 & 8 & 16.00 & 1.927 & 2.617 & .017 & $*$ \\
\hline Dependent decision making & 13 & 14.46 & 2.066 & 8 & 12.25 & 4.803 & 1.234 & .250 & \\
\hline Avoidant decision making & 13 & 18.00 & 2.121 & 8 & 13.88 & 3.482 & 3.023 & .012 & $*$ \\
\hline $\begin{array}{l}\text { Melbourne Decision Making } \\
\text { Questionnaire MDMQ }\end{array}$ & & & & & & & & & \\
\hline Vigilance & 13 & 12.08 & 1.706 & 8 & 11.63 & .518 & .891 & .387 & \\
\hline Buck-passing & 13 & 14.46 & 3.777 & 8 & 14.13 & 4.291 & .183 & .858 & \\
\hline Procrastination & 13 & 11.23 & 2.743 & 8 & 11.88 & 2.295 & .579 & .570 & \\
\hline Hypervigilance & 13 & 9.92 & 2.660 & 8 & 9.13 & 2.232 & .739 & .470 & \\
\hline
\end{tabular}


Women with low response to lack of structure used more frequently the intuitive decision making and less frequently avoidant decision making style.

Women with different degree of response to lack of structure, similarly to desire for structure, did not differ significantly in the behavior studied by the Melbourne Questionnaire.

In the extreme groups of women, divided according to the overall score in the personal need for structure (PNS) (Table 3), significant differences were found in the rational decision making style, similar to those in women divided according to the desire for structure, i.e., women with low personal need for structure used less frequently rational decision making styles. On the other hand, women with low personal need for structure (similarly to women with low response to lack of structure) used more frequently intuitive decision making and less frequently avoidant decision making styles.
Even the overall personal need for structure in the studied sample did not significantly affect decision making behavior.

\section{Counterfactual Thinking and Decision Making}

A t-test was used to assess the relationship between decision making styles as well as decision making behavior with four aspects of counterfactual thinking (counterfactual thinking frequency, saddening by counterfactual thinking, help or inhibition by counterfactual thinking in solving future problems).

No significant differences were found in the relationship of counterfactual thinking frequency and individual decision making styles and decision making behavior styles (Table 4).

The relationship between saddening by counterfactual thinking and individual deci-

Table 4. Comparison of women with low and high frequency of counterfactual thinking (CT) and decision making styles, decision making behavior

\begin{tabular}{|c|c|c|c|c|c|c|c|c|c|}
\hline \multirow{2}{*}{ Women } & \multicolumn{3}{|c|}{ Rare CT } & \multicolumn{3}{|c|}{ Frequent CT } & \multirow{2}{*}{$\mathrm{t}$} & \multirow{2}{*}{ sig } & \multirow[b]{2}{*}{$\mathrm{p}$} \\
\hline & N1 & AM1 & SD1 & $\mathrm{N} 2$ & AM2 & SD2 & & & \\
\hline $\begin{array}{l}\text { Decision Making Style } \\
\text { Ouestionnaire DMSOO }\end{array}$ & & & & & & & & & \\
\hline Rational decision making & 27 & 18.11 & 3.786 & 46 & 18.26 & 4.117 & .158 & .875 & \\
\hline Intuitive decision making & 28 & 14.64 & 2.345 & 47 & 14.85 & 2.734 & .349 & .728 & \\
\hline Dependent decision making & 28 & 12.11 & 2.767 & 48 & 12.23 & 3.347 & .171 & .864 & \\
\hline Avoidant decision making & 28 & 14.82 & 3.454 & 48 & 15.81 & 3.227 & 1.236 & .222 & \\
\hline $\begin{array}{l}\text { Melbourne Decision Making } \\
\text { Questionnaire MDMQ }\end{array}$ & & & & & & & & & \\
\hline Vigilance & 28 & 11.75 & 1.236 & 48 & 12.08 & 1.164 & 1.159 & .252 & \\
\hline Buck-passing & 28 & 14.04 & 2.631 & 47 & 12.64 & 4.067 & 1.805 & .075 & \\
\hline Procrastination & 28 & 11.32 & 2.195 & 47 & 10.38 & 2.642 & 1.657 & .102 & \\
\hline Hypervigilance & 27 & 9.93 & 1.920 & 48 & 9.04 & 2.021 & 1.878 & .066 & \\
\hline
\end{tabular}


sion making styles and decision making behavior (Table 5) revealed that women more frequently saddened by counterfactual thinking use significantly more often the dependent decision making style, as well as maladaptive behavior, i.e., buck-passing, procrastination and hypervigilance.
Women who say that counterfactual thinking is not helpful (Table 6) significantly less frequently use rational decision making style and more frequently maladaptive behavior in the form of buck-passing.

Women who are inhibited by counterfactual thinking in their problem solving (Table

Table 5. Comparison of women with strong and weak saddening effect of counterfactual thinking (CT) and decision making styles, decision making behavior

\begin{tabular}{|l|c|c|c|c|c|c|c|c|c|}
\hline \multirow{2}{*}{ Women } & \multicolumn{2}{|c|}{ CT rarely saddens } & \multicolumn{2}{c|}{ CT often saddens } & \multirow{2}{*}{$\mathrm{t}$} & \multirow{2}{*}{ sig } & $\mathrm{p}$ \\
\cline { 2 - 12 } & N1 & AM1 & SD1 & N2 & AM2 & SD2 & & & \\
\hline $\begin{array}{l}\text { Decision Making Style } \\
\text { Questionnaire DMSQ }\end{array}$ & & & & & & & & & \\
\hline Rational decision making & 42 & 18.10 & 3.484 & 31 & 18.35 & 4.608 & .263 & .794 & \\
\hline Intuitive decision making & 43 & 14.84 & 2.636 & 32 & 14.69 & 2.546 & .248 & .805 & \\
\hline Dependent decision making & 44 & 13.00 & 2.753 & 32 & 11.06 & 3,301 & 2.705 & .009 & $*$ \\
\hline Avoidant decision making & 44 & 15.66 & 3.147 & 32 & 15.16 & 3.584 & .635 & .528 & \\
\hline $\begin{array}{l}\text { Melbourne Decision Making } \\
\text { Questionnaire MDMQ }\end{array}$ & & & & & & & & & \\
\hline Vigilance & 44 & 11.73 & 1.086 & 32 & 12.28 & 1.276 & 1.988 & .051 & \\
\hline Buck-passing & 43 & 14.21 & 3.044 & 32 & 11.75 & 3.943 & 2.937 & .005 & $* *$ \\
\hline Procrastination & 44 & 11.43 & 2.139 & 31 & 9.74 & 2.695 & 2.905 & .005 & $* *$ \\
\hline Hypervigilance & 44 & 9.86 & 1.825 & 31 & 8.65 & 2.090 & 2.618 & .011 & $*$ \\
\hline
\end{tabular}

Table 6. Comparison of women who find counterfactual thinking (CT) helpful and not helpful and decision making styles, decision making behavior

\begin{tabular}{|c|c|c|c|c|c|c|c|c|c|}
\hline \multirow{2}{*}{ Women } & \multicolumn{3}{|c|}{ CT not helpful } & \multicolumn{3}{|c|}{ CT helpful } & \multirow{2}{*}{$\mathrm{t}$} & \multirow{2}{*}{ sig } & \multirow{2}{*}{$\mathrm{p}$} \\
\hline & N1 & AM1 & SD1 & N2 & AM2 & SD2 & & & \\
\hline \multicolumn{10}{|l|}{$\begin{array}{l}\text { Decision Making Style } \\
\text { Questionnaire DMSQ }\end{array}$} \\
\hline Rational decision making & 25 & 20.32 & 3.375 & 48 & 17.10 & 3.838 & 3.682 & .001 & $* * *$ \\
\hline Intuitive decision making & 25 & 14.32 & 2.231 & 50 & 15.00 & 2.733 & 1.152 & .254 & \\
\hline Dependent decision making & 25 & 11.88 & 2.698 & 51 & 12.33 & 3.333 & .636 & .528 & \\
\hline Avoidant decision making & 25 & 15.72 & 3.076 & 51 & 15.31 & 3.461 & .519 & .606 & \\
\hline \multicolumn{10}{|l|}{$\begin{array}{l}\text { Melbourne Decision Making } \\
\text { Questionnaire MDMQ }\end{array}$} \\
\hline Vigilance & 25 & 12.08 & 1.412 & 51 & 11.90 & 1.082 & .556 & .582 & \\
\hline Buck-passing & 25 & 11.40 & 4.072 & 50 & 14.04 & 3.090 & 2.856 & .007 & $* *$ \\
\hline Procrastination & 24 & 9.88 & 2.692 & 51 & 11.14 & 2.341 & 1.973 & .055 & \\
\hline Hypervigilance & 25 & 8.92 & 1.913 & 50 & 9.58 & 2.051 & 1.375 & .175 & \\
\hline
\end{tabular}


Table 7. Comparison of women who are and are not inhibited by counterfactual thinking (CT) and decision making styles, decision making behavior

\begin{tabular}{|l|r|r|r|r|r|r|r|r|l|}
\hline \multirow{2}{*}{ Women } & \multicolumn{3}{|c|}{ CT does not inhibit } & \multicolumn{3}{c|}{ CT inhibits } & \multirow{2}{*}{$\mathrm{t}$} & \multirow{2}{*}{ sig } & \multirow{2}{*}{$\mathrm{p}$} \\
\cline { 2 - 11 } & N1 & AM1 & SD1 & N2 & AM2 & SD2 & & & \\
\hline $\begin{array}{l}\text { Decision Making Style } \\
\text { Questionnaire DMSQ }\end{array}$ & & & & & & & & & \\
\hline Rational decision making & 49 & 17.65 & 3.903 & 24 & 19.33 & 3.953 & 1.713 & .093 & \\
\hline Intuitive decision making & 51 & 14.80 & 2.698 & 24 & 14.71 & 2.368 & .156 & .877 & \\
\hline Dependent decision making & 52 & 12.40 & 2.966 & 24 & 11.71 & 3.470 & .849 & .401 & \\
\hline Avoidant decision making & 52 & 15.19 & 3.548 & 24 & 16.00 & 2.766 & 1.078 & .285 & \\
\hline $\begin{array}{l}\text { Melbourne Decision Making } \\
\text { Questionnaire MDMQ }\end{array}$ & & & & & & & & & \\
\hline Vigilance & 52 & 11.88 & 1.114 & 24 & 12.13 & 1.361 & .756 & .454 & \\
\hline Buck-passing & 51 & 14.20 & 2.953 & 24 & 10.96 & 4.038 & 3.511 & .001 & $* * *$ \\
\hline Procrastination & 52 & 11.40 & 2.079 & 23 & 9.22 & 2.779 & 3.378 & .002 & $* *$ \\
\hline Hypervigilance & 51 & 9.65 & 1.978 & 24 & 8.75 & 2.005 & 1.815 & .076 & \\
\hline
\end{tabular}

7) significantly more often use buck-passing and procrastination.

\section{DISCUSSION}

Analysis of the overall PNS and its components confirmed the hypothesis that in the studied relationships, the individual components of PNS are really applied differently.

The comparison of women with low and high desire for structure that focuses mainly on the extent to which individuals wish for a simple structure in their daily life showed that women who manifest low desire for structure do not use frequently rational, as well as dependent decision making style.

The rational approach is based rather on data and arguments than on subjective preference and feelings (Bakošová, Uhlář, 2012). This may explain why women with high desire for structure and high personal need for structure use more frequently rational deci- sion making, i.e., they consciously assess alternatives with the aim to choose the most effective one.

In agreement with the characteristics of the dependent decision making style, i.e., supporting of others in their decisions, it is not a surprise that women with high desire for structure use the dependent decision making style more frequently.

A different situation occurred in the comparison of women with a different score in response to lack of structure as well as the total score in personal need for structure and decision making styles studied by the Decision Making Style Questionnaire. High response to lack of structure, related to negative affect as a response to, e.g., a chaotic, unorganized event, is in women related to more frequent avoidant decision making style. This finding is in accordance with a well known fact that negative emotions (e.g., anxiety, fear, etc.) relate to escape or avoidant behavior. 
On the other hand, women with high response to lack of structure and high total score in personal need for structure used less frequently the intuitive decision making style.

According to Bakošová and Uhlář (2012), the intuitive approach is based on subjective preference, which is not necessarily supported by rational argumentation. Reber (1993) perceives intuition as an aspect of expertise and so called "tacit knowledge", which are dependent on the interaction between an individual and the environment. According to Sternberg (2004), successful managers are characterized by hidden, socalled "tacit knowledge", which is knowledge usually obtained without direct help from others. Many other authors (e.g., Reber, 1993) mention implicit learning and obtaining knowledge on cognitive structures that individuals use to make judgments in the decision making process. Agor (1986) suggested that intuition in decision making appears mainly in the case when the facts and information available are contradictory and vague and new solutions of problems in rapidly changing environments or crisis settings are necessary. Isenberg (1984) also stated that individuals rely upon intuition in complex, new and extremely complicated situations. Gigerenzer and Brighton (2009) suggested that in certain situations less information can in fact improve the accuracy of decision making. Similarly, Shirley and Langan-Fox (1996) argued for the use of intuition in decisionmaking, especially when uncertainty is high, variables are less predictable, facts are limited, and little precedent exists. Shapiro and Spence (1997) proposed that problems lie on a continuum of structuredness. Unstructured problems are conducive to intuition because of the absence of well-accepted decision rules for dealing with such situations. For this reason, intuitive judgments are said to become more effective relative to rational analysis as a problem becomes increasingly unstructured.

Exactly these findings may be the reason why women with low personal need for structure as well as with low response to lack of structure use significantly more frequently intuitive decision making style, as their decisions are based on "tacit knowledge" rather than on structure. At the same time, lower personal need for structure in women using the intuitive decision making style more frequently is probably related to the significantly lower response to lack of structure. These findings are in agreement with the intuitive decision making style subscale, characterized by decision making based on experience.

As opposed to Sarmány-Schuller (1999), who found that individuals with high personal need for structure make decisions quicker and procrastinate less, results of the presented research did not show any significant relationships between personal need for structure as well as its components (desire for structure and response to lack of structure) and behavior styles in the decision making process studied by the Melbourne Questionnaire.

The fact that we did not find significant relationships, contrary to Sarmány-Schuller, could be caused by the low number of respondents and that is why these results require further research on a more representative sample.

Counterfactual thinking, i.e. thinking about something that did not happen may, at first glance, appear as unproductive, ineffective and so as wasting time. However, intentional and systematic contemplation about alternative realities is more important than mere 
unproductive daydreaming (Bačová, 2009). It should be a constituent part of analysis and strategy or better said, no analysis or strategy can be done without counterfactual thinking (Hendrickson, 2008). However, no significant differences were found in the relationship between counterfactual thinking frequency and individual decision making styles as well as decision making behavior styles.

Similar results were also achieved by Konrádová and Mihálik (2011) in an analogous research on the relationship of counterfactual thinking and decision making behavior styles, carried out by means of the Counterfactual Thinking Questionnaire and Melbourne Decision Making Questionnaire. Thus, it should be supposed that frequency of counterfactual thinking affects neither decision making style, nor decision making behavior.

Contrary to the frequency of counter-factual thinking, the study found relationships between saddening by counterfactual thinking and individual decision making styles and decision making behavior. Women more frequently saddened by counterfactual thinking use significantly more often dependent decision making style, as well as maladaptive behavior, i.e., buck-passing, procrastination and hypervigilance.

Recent study of post-decision regret resulted in the formulation of the counterfactual thinking theory. According to this theory, post-decision regret is not necessarily the result of negative feedback or result, but it is affected by the alternative closest to the outcome. Thus, it can be assumed that anticipated as well as additional regret have a direct influence on the quality of the decision and final satisfaction with a person's own decision (Bakošová, Uhlář, 2012).
According to Janis and Mann (1977), anticipated regret is given by experience that teaches an individual to prevent hasty decisions, makes him/her consider different alternatives and their consequences and evaluate the possible results. The necessary requirement is the ability to put aside one's own needs and their satisfaction, which in some cases may lead to extreme procrastination. The authors also speak about additional regret, which results from negative feedback or negative consequences of decision making. It may result in defensive avoidance, i.e., unwillingness to respond to negative consequences - procrastination, and increased or extreme vigilance, sensitivity to feedback - hypervigilance.

In contrast to the presented research, Konrádová and Mihálik (2011) did not find any relationship between decision making behaviors with the degree of saddening by counterfactual thinking, apart from a similar relationship to hypervigilance. Authors say that hypervigilance is a form of decision making characterized by incorrectly directed activity. People search for solutions in the nick of time, under time pressure and emotional stress. The basic prerequisite for regret is focus on one's own actions, thus hypervigilance as typical decision maker's activity is related to saddening by counterfactual thinking.

This research does not confirm the findings of Bakošová and Uhlář (2012) that a decision is followed by a feeling of regret in those participants who used rational approach to arrive at a decision and not the intuitive one. There were found no significant differences in the use of the rational or intuitive decision making style in the women sample in relation to the degree of saddening by counterfactual thinking. 
On the other hand, women who say that counterfactual thinking is not helpful significantly less frequently use rational decision making style and more frequently maladaptive behavior in the form of buck-passing. It seems that these women do not take the advantage of rational processing of various alternatives and they prefer to get rid of responsibility for the decision.

In adolescents who do not find counterfactual thinking helpful, Konrádová and Mihálik (2011) found not only more frequent buck-passing, but also significantly more frequent procrastination. In the presented sample of women, the same relationship was borderline significant (sig. 0.055). Buck-passing and procrastination are defensive, avoidant decision making behavior styles. Such passive decision making behavior styles do not have to, influenced by the inability to decide to act, lead to a corresponding corrective behavior (Konrádová, Mihálik, 2011).

Finally, the results show that women who are inhibited by counterfactual thinking in their problem solving significantly more often use buck-passing and procrastination. Contemplating various alternatives possibly leads to postponing decisions and thus an individual may consider such thinking counterproductive. Konrádová and Mihálik (2011) found in this case, in addition to relationships found by the presented research, more frequent hypervigilance in adolescents, who are inhibited by counterfactual thinking in their problem solving. According to the authors, these maladaptive styles are related to high levels of stress in decision making and can decrease the degree to which counterfactual thinking fulfills a behavioral regulation function.

\section{CONCLUSION}

The main goal was to study the relationships between Personal Need for Structure, counterfactual thinking and decision making styles and behavior in the decision making process. The research revealed relationships between variables, and the most significant findings are that personal need for structure and its components do not affect decision making behavior of individuals but affect the decision making style in a differentiated way, depending on whether desire for structure or response to lack of structure is concerned. Strong desire for structure is related to a more frequent use of rational and more dependent decision making styles, while a weak response to lack of structure is related to a more frequent use of intuitive decision making style and less frequent avoidant decision making style. The results of this research thus confirm the legitimacy of the two-factor character of personal need for structure and the different relationships of these two subfactors to different personality constructs.

Moreover, the study found that the characteristics of counterfactual thinking (saddening, helpfulness and inhibiting by counterfactual thinking, but not its frequency) are especially related to maladaptive decision making behavior.

Limitations of the research presented are obvious. The research sample is small and not representative of the whole population. Results must be validated on a larger sample, comprising not only women but men as well.

Received April 10, 2014 


\section{REFERENCES}

AGOR, W., 1986, The logic of intuition: How top executives make important decisions. Organizational Dynamics, 14, 3, 5-18.

BAČOVÁ, V., 2009, Kontrafaktové myslenie ako súčast' rozhodovania. In: Z. Ruiselová a kol. Kontrafaktové myslenie a osobnost' (pp. 43-62). Bratislava: Slovak Academy Press.

BAČOVÁ, V., 2011a, Klasická a ekologická racionalita v rozhodovaní: spor o heuristiky. In: V. Bačová (Ed.), Rozhodovanie a usudzovanie II., Oblasti a koncepcie (pp. 105-130). Bratislava: Ústav experimentálnej psychológie SAV.

BAČOVÁ, V., 2011b, Hladanie štandardov usudzovania a rozhodovania. In: K. Bartošová, M. Čerňák, P. Humpolíček, M. Kukaňová, A. Slezáčková (Eds.), Sociální procesy a osobnost, Člověk na cestě životem: Křižovatky a mosty, Sborník př́spěvki̊, Kroměříž, Sept. 14-16, 2011 (pp. $17-$ 20). Brno: Tribun EU.

BAKOŠOVÁ, N., UHLÁŘ, P., 2012, Prožívání a strategie $\mathrm{V}$ procesu rozhodování $\mathrm{v}$ kontextu kognitivního stylu a osobnosti. In: L. Pilárik, I. Sarmány-Schuller (Eds.), Rozhodovanie v kontexte kognície, osobnosti a emócii III., zborník z medzinárodnej vedeckej konferencie. Nitra: FSVaZ UKF v Nitre.

BAR-TAL, Y., RAVIV, A., SPITZER, A., 1999, The need and ability to achieve cognitive structuring: Individual differences that moderate the effect of stress on information processing. Journal of Personality and Social Psychology, 77, 1, 33-51.

BLAIS, A.-R., THOMPSON, M.M., BARANSKI, J.V., 2003, The effects of individual difference in cognitive styles on decision-making accuracy and latency. Technical Report, Defence Research and Development Canada Toronto (DRDC Toronto), Toronto, Canada.

COHEN, A.R., STOTLAND, E., WOLFE, D.M. 1955, An experimental investigation of need for cognition. Journal of Abnormal Social Psychology, 51, 291-294.

ČEREŠNÍK, M., 2010, Percipovanie kontroly a rozhodovacie štýly u vysokoškolských študentov/ študentiek. In: I. Sarmány-Schuller, L. Pilárik, E. Jurišová (Eds.), Rozhodovanie v kontexte kognicie, osobnosti a emócií II. Nitra: UKF.

ČEREŠNÍK, M., 2012, Decision-making and cognitive structuring of students at university. Procedia - Social and Behavioral Sciences, 55, 196-205.
GIGERENZER, G., BRIGHTON, H., 2009, Homo heuristics: Why biased minds make better inferences. Topics in Cognitive Science, 1, 107-143.

HENDRICKSON, N., 2008, Counterfactual reasoning. A basic guide for analysts, strategists, and decision makers. The Proteus Monograph Series, Vol. 2, Issue 5. http://www.csl.army.mil/usacsl/publications/Hendrickson_Counterfactual_Reasoning. pdf

JANIS, I.L., MAN, L., 1977, Decision making: A psychological analysis of conflict, choice, and commitment. New York: Free Press.

KAHNEMAN, D., TVERSKY, A., 1979, Prospect theory: An analysis of decision under risk. Econometrica, 47, 263-291.

KAPLAN, M.F., WANSHULA, L.T., ZANNA, M.P., 1991, Time pressure and information integration in social judgment: The effect of need for structure. In: 0. Svenson, J. Maule (Eds.), Time pressure and stress in human judgment and decisionmaking (pp. 225-267). Cambridge, U.K.: Cambridge University Press

KONRÁDOVÁ, L', MIHÁLIK, J., 2011, Rozhodovanie a kontrafaktové myslenie v kontexte rozhodovania o vol'be povolania. In: K. Bartošová, M. Čerňák. P. Humpolíček, M. Kukaňová, A. Slezáčková (Eds.), Sociálni procesy a osobnost, Člověk na cestě životem: Křižovatky a mosty, Sborník príspěvků, Kroměříž, Sept. 14-16, 2011 (pp. 125131). Brno: Tribun EU.

KRUGLANSKI, A.W., 1989, Lay epistemics and human knowledge: Cognitive and motivational bases. New York: Springer.

KRUGLANSKI, A.W., FREUND, T., 1983, The freezing and unfreezing of lay inferences: Effects on impressional primacy, ethnic stereotyping, and numerical anchoring. Journal of Experimental Social Psychology, 19, 448-468.

MANN, L., BURNETT, P., RADFORD, M., FORD, S., 1997, The Melbourne Decision Making Questionnaire: An instrument for measuring patterns for coping with decisional conflict. Journal of Behavioral Decision Making, 10, 1, 119.

MELLERS, B.A., SCHWARTZ, A., RITOV, I., 1999, Emotion-based choice. Journal of Experimental psychology: General, 128, 332-345.

MCKENZIE, C.R.M., 2005, Judgment and decision making. In: K. Lamberts, R.L. Goldstone (Eds.), Handbook of cognition (pp. 321-338). London: Sage.

NEUBERG, S.L. NEWSOM, J.T., 1993, Personal need for structure: Individual differences in the de- 
sire for simple structure. Journal of Personality and Social Psychology, 65, 1, 113-131.

REBER, A.S., 1993, Implicit learning and tacit knowledge: An essay on the cognitive unconscious. New York: Oxford University Press.

RUISEL, I., 2004, Inteligencia a myslenie. Bratislava: Ikar.

RUISELOVÁ, Z., 2009, Kontrafaktové myslenie. In: Z. Ruiselová a kol. (Eds.), Kontrafaktové myslenie a osobnost' (pp. 7-28). Bratislava: Slovak Academic Press.

RUISELOVÁ, Z., PROKOPČÁKOVÁ, A. KRESÁNEK, J., 2007, Counterfactual thinking in relation to the personality of women - doctors and nurses. Studia Psychologica, 49, 4, 333-339.

RUISELOVÁ, Z., PROKOPČÁKOVÁ, A., KRESÁNEK, J., 2012, Personal need for structure related to counterfactual thinking and wisdom. Studia Psychologica, 54, 4, 287-297.

SARMÁNY-SCHULLER, I., 1987, Oscillation of measures of cognitive style (field dependence-independence) in situation of sleep deprivation. Studia Psychologica, 29, 125-132.

SARMÁNY-SCHULLER, I., 1997, Potreba štruktúry ako bariéra kognitívnej adjustácie adolescentov. In: Z. Ruiselová (Ed.), Bariéry kognitívnej a sociálnej adjustácie $u$ adolescentov (pp. 52-68). Bratislava: Ústav Experimentálnej Psychológie SAV.

SARMÁNY-SCHULLER, I., 1999, Procrastination, need for cognition and sensation seeking. Studia Psychologica, 41, 1, 73-85.

SARMÁNY-SCHULLER， I., 2001, Potreba štruktúry a schopnost' vytvárania štruktúry ako osobnostné konštrukty. In: I. Sarmány-Schuller (Ed.), Psychológia pre bezpečný svet, Zbornik prispevkov zXI. Zjazdu SPS (pp. 336-339). Bratislava: Stimul.

SARMÁNY-SCHULLER, I., 2009, Rozhodovanie ako problém súčasných psychologických výskumov. In: IV. medzinárodná konferencia doktorandov odborov Psychológia a Sociálna práca (pp. 8-12). Nitra: UKF.

ŠIMÚTH, J., SARMÁNY-SCHULLER, I., 2010 , Cognitive and decision making styles. In: M.H Pedrosa-de Jesus, C. Evans, Z. Charlesworth, E. Cools (Eds.), ELSIN XV, Exploring styles to enhance learning and teaching in diverse contexts. Proceedings of the 15th Annual Conference of the European Learning Styles Information Network (pp. 467-470). An international, mutli-disciplinary conference, June 28-30, 2010, Aveiro, Portugal.
ŠIMÚTH, J., SARMÁNY-SCHULLER, I., 2011, Kognitívne a rozhodovacie štýly v manažérskom rozhodovaní. In: M. Bratská (Ed.), Cesty k múdrosti (Ways to Wisdom), 29. Psychologické dni, Zborník príspevkov (pp. 532-537). Bratislava: Stimul.

ŠIMÚTH, J., jr., SARMÁNY-SCHULLER, I., 2013, Aplikácia výskumu v oblasti kognitívneho a rozhodovacieho štýlu vo vzdelávaní a manažmente. In: I. Sarmány-Schuller (Ed.), Otázniky rozhodovania: Teória, empíria, život. 31. Psychologické dni, Zbornik príspevkov (pp. 343-347). Bratislava: Stimul.

SCOTT, S.G., BRUCE, R.A., 1995, Decision Making Style, the development and assessment of a new measure. Educational and Psychological Measurement, 55, 5, 818-831.

SHAPIRO, S., SPENCE, M.T., 1997, Managerial intuition: A conceptual and operational framework. Business Horizons, 40, 1, 63-68.

SHIRLEY, D.A., LANGAN-FOX, J., 1996, Intuition: A review of the literature. Psychological Reports, 79, 563-584.

SOLLÁR, T., 2005, Potreba kognitívnej štruktúry $v$ kontexte osobnostných a interpersonálnych premenných. Bratislava: Ústav Experimentálnej Psychológie SAV, Dizertačná práca.

STERNBERG, R.J., 2002, Kognitivni psychologie. Praha: Portál.

STERNBERG, R.J., 2004, Prečo robia múdri ludia hlúposti? 1. vyd. Bratislava: Ikar.

STRANOVSKÁ, E., SARMÁNY-SCHULLER, I., MUNK, M., MUNKOVÁ, D., 2011, Kognitívna štrukturácia $\mathrm{v}$ kontexte verbálnej produktivity. In: M. Bratská (Ed.), Cesty k múdrosti (Ways to Wisdom), Zbornik príspevkov, 29. Psychologické dni (pp. 517-524). Bratislava: STIMUL

SVENSON, O., 2003, Values, affect and processes in human decision making: A differentiation and consolidation theory perspective. In: S.L. Schneider, J. Shanteau (Eds.), Emerging perspectives on judgment and decision research (pp. 287-326). Cambridge: Cambridge University Press.

THOMPSON, M.M., NACCARATO, M.E., PARKER, K.C.H., MOSKOWITZ, G.B., 2001, The personal need for structure and personal fear of invalidity measures: Historical perspectives, current applications, and future directions. In: G.B. Moskowitz (Ed.), Cognitive social psychology: The Princeton symposium on the legacy and future of social cognition (pp. 19-40). NJ: Erlbaum.

TODD, P.M., GIGERENZER, G., 2003, Bounding rationality to the world. Journal of Economic Psychology, 24, 143-165. 
WOLFRADT, U., ENGELMANN, S., 1999, Depersonalization, fantasies, and coping behavior in clinical context. Journal of Clinical Psychology, $55,2,225-232$.

\section{OSOBNÁ POTREBAŠTRUKTÚRY, KONTRAFAKTOVÉ MYSLENIE A ROZHODOVANIE UŽIEN}

\section{A. P r o k o p č á k o vá}

Súhrn: Ciel'om štúdie je prispiet' k objasneniu vzájomných vzt'ahov potreby štruktúry, kontrafaktového myslenia a štýlov rozhodovania. Výskumný výber tvorilo 76 vysokoškolských študentiek. Administrovali sme škály: Osobná potreba štruktúry (PNS), Melbournský dotazník rozhodovania (MDMQ), Dotazník rozhodovacieho štýlu (DMSQ) a dotazník Premýšl'anie o neuskutočnených alternatívach riešenia (KM). Zistili sme, že potreba štruktúry a jej zložky neovplyvňujú spôsob správania sa jednotlivcov pri rozhodovacom procese, ale ovplyvňujú štýl rozhodovania, a to diferencovane $\mathrm{v}$ závislosti od toho, či sledujeme želanie štruktúry alebo reakciu na chýbanie štruktúry. Silné želanie štruktúry súvisí s častejším používaním racionálneho a závislého štýlu rozhodovania, zatial' čo slabá reakcia na chýbanie štruktúry súvisí s častejším používaním intuitívneho štýlu rozhodovania a zriedkavejším vyhýbavým štýlom rozhodovania. Okrem toho sme zistili, že charakteristiky kontrafaktového myslenia súvisia najmä s maladaptívnymi štýlmi správania sa pri rozhodovaní. 